Article

\title{
Industry-Practice-Based Engineering Hydrology Education at USQ, Australia
}

\author{
Rezaul Chowdhury
}

School of Civil Engineering and Surveying, University of Southern Queensland, Toowoomba, QLD 4350, Australia; Rezaul.Chowdhury@usq.edu.au

Received: 7 June 2019; Accepted: 9 August 2019; Published: 11 August 2019

\begin{abstract}
Engineering education must embrace several challenges, such as increased numbers of work-based students, increased demand for online education, mismatches in employability skills and industry requirements, and lack of student engagement. The hydrology course at the University of Southern Queensland attracts more than 100 students every year, where more than $70 \%$ of students are off-campus and most of them are work-based. This study explored how an online hydrology course can embrace industry practice and engage students in order to achieve learning outcomes. Industrial careers in hydrology involve extensive use of hydroclimatological data and modeling applications. The course modules, learning objectives and outcomes, and assessment tools have been designed to align with industry practices. Active participation of students was observed in self-assessment quizzes and discussion forums. The course was rated very well in achieving learning outcomes and in overall student satisfaction. Students appreciated the well-structured real-world and professional practice in the course.
\end{abstract}

Keywords: hydrology; online education; industry practice; competency

\section{Introduction}

Hydrology education involves teaching the occurrence, distribution, and movement of water through description, explanation, and prediction [1]. Ruddell and Wagener [2] reviewed the historical development of engineering hydrology education from the middle of the 20thcentury. They identified three major landmarks in hydrology education. The first landmark was observed in the 1960s, when many universities began formally offering hydrology education, followed by the second landmark in the 1990s, when field practice methods, professional and business skills, and engineering licensure requirements evolved. Formal university hydrology programs were established after the second landmark [2]. The third landmark was observed in the 2000s, fostered by advancements of research in science, technology, engineering and mathematics (STEM), availability of internet-based resources, modeling packages, geographical information systems (GIS) and hydro-informatics, and increased public awareness of climate change and its consequences for natural resource availability. Industrial careers in hydrology involve the extensive use of data (climate, stream flow, and GIS, for example) and modeling applications [1]. Therefore, there is a need for hydrology students to learn these skills. The availability of resources such as models, data, and scientific toolsets has created the opportunity to include these new resources in hydrology curricula [1].

Most engineering courses including hydrology are now being offered based on a variety of different eTools, and many of them are now online courses [3,4]. Based on the percentage of online course delivery component, Allen and Seaman [5] categorized tertiary courses into four types. Traditional courses do not include online delivery, whereas web-facilitated courses include $1 \%$ to $29 \%$, blended or hybrid courses include $30 \%$ to $79 \%$, and online courses contain $80 \%$ to $100 \%$ online delivery components. Several studies have investigated how well each category performs. Rahman [3] mentioned that many 
engineering programs in industrialized countries are now following a blended or hybrid approach. A blended approach is a flexible learning approach, which integrates both face-to-face and online course delivery methods. However, student engagement in a blended or online course is becoming a challenge. In a student-centered learning approach, different active learning methods, such as problemand case-based learning, role-play, and group work, are highly encouraged. Nevertheless, these methods are difficult to apply in an online or hybrid course. According to Reeves et al. [6], the design of complex activities for the students is a central component of online course delivery. Problems in online courses should be designed in such a way that students have to learn, assess, and demonstrate their skills through a series of challenging tasks. Incorporating hands-on tasks for practical problem solving offers significant value to engineering graduates.

Collaboration with industries (including consultancy and public administration) isstrongly encouraged in engineering education [7]. According to Smith et al. [8], engaging students and academic staff with industries produces better-trained engineering graduates, as well as adding benefits to the industries. Internships, co-op programs with industries, and industry-sponsored research projects are the conventional ways of developing collaboration with industries. Based on case studies in six universities in the United Kingdom, Arlett et al. [9] explored the drivers for experience-led engineering programs. Their study revealed that academic staff experience of industry, industry input to teaching and curricula, student experience of industry, and feedback to curriculum all are important for a successful experience-led engineering program.

Several studies have pointed out existence of competency deficiencies or skills gaps in engineering graduates, based on employers' perceptions [10-16]. A competency deficiency is the difference between the level of competence required for employment and the level of competence of graduates [17]. Bodmer et al. [10] observed major competency deficiencies in communication, leadership, and social skills in Europe and the United States. Competency gaps were observed in practical applications and business skills of engineering graduates in the United Kingdom [11]. World Chemical Engineering Council (WCEC) [12] explored competency deficiencies in business skills, project management, communication, and leadership skills in an international study conducted in 63 countries. In Australia [13], skill gaps have been identified in accountability, teamwork, communication, and interpersonal skills, whereas a different study observed deficiencies in communication and business skills [16]. Nair et al. [14] also reported skill gaps in communication, teamwork, problem solving, and time management skills, as well as in application of knowledge in the workplace. Scott and Yates [15] identified skill gaps in emotional intelligence of graduates. According to WCEC [12], the highest competency deficiencies in Australian engineering graduates were identified in business approach, followed by quality management methods, project management methods, management skills, and effective communication and leadership skills.

Williams [18] identified skill gaps in problem solving and communication skills as part of a review of engineering education in Australia. Later, Johnson [19] identified major skill gaps in interpersonal skills, communication skills, teamwork skills, creativity, innovation, design, and problem solving skills. In a recent review of engineering education in Australia, Johnson et al. [20] identified competency deficiencies in written communication skills, fundamental science and engineering knowledge, practical experience, familiarity with industry standards, codes, and financial constraints, and in engineering project management skills. Their study identified an improvement in teamwork and application of software tools. Male et al. [17] pointed out practical engineering and engineering business skills gaps in Australian engineering graduates. Practical engineering competency gaps included familiarity with sites, tools, and methods, and applications in common industries, whereas business competency deficiencies included relationships between contractors, consultants, and clients, engineering planning, specification, estimation, project management, cost control, and risk management [17]. Mismatch in skills is one of the key factors for engineering graduates' struggles in industry recruitment [21]. Therefore, well-designed course outcomes linked to industrial practice have significant importance for the employability of engineering graduates. 
The nature of the student population and their enrolment in engineering programs are changing. Students' enrolment in engineering programs has decreased, but has increased in less-technical programs [22]. The number of work-based students is increasing [9]. Consequently, there is a growing demand for online engineering education. However, developing a student-centered and industry-focused online engineering education course really is a challenge for engineering educators. The hydrology course at the University of Southern Queensland (USQ) in Australia (course code: ENV3105, description: Hydrology) has been designed to incorporate industrial practice in learning outcomes, teaching, and assessment strategies. The course is designed to accommodate work-based students, and to increase their engagement while minimizing the competency gaps of the engineering graduates. Therefore, the main objectives of this study were to develop an industry-focused online engineering hydrology course and to assess its success in terms of student engagement and achievement of course learning outcomes.

\section{Materials and Methods}

\subsection{Course Description}

ENV3105 Hydrology is a third-year water engineering course offered to undergraduate students with civil, agricultural, and environmental engineering majors. The course also attracts students from a small number of postgraduate programs [23]. It provides the basic skills needed to carry out the hydrological analyses and designs that are frequently used in Australian engineering practice. The course involves design of storm water drainage systems, flood and flood management, yield from water supply catchments, and groundwater systems. It includes hydrological techniques practiced by professional engineers, including those codified in the Australian Rainfall and Runoff-A Guide to Flood Estimation [24]. The course is a one-unit course (expected student workload is $155 \mathrm{~h}$ ), offered every year in Semester 2 (July to November). More than 100 students generally take the course, and more than $70 \%$ of enrolled students are online or external [23]. ENV3105 course content (modules), weightage, and corresponding course objectives (learning objectives) are provided at https://www.usq.edu.au/course/specification/2018/ENV3105-S2-2018-ONC-SPRNG.html.

All students, irrespective of their off-campus or on-campus enrolment, have access to the USQ learning management system (USQ StudyDesk), which contains lectures, the study book and other course materials, assignments, tutorials, and discussion forums in which students can interact and post questions. The course involves a 2 hour lecture and a 2 hour tutorial session every week for the on-campus students. Recorded lectures and tutorial sessions are uploaded to StudyDesk. Off-campus students can participate in the lectures and tutorial sessions physically or using a video conferencing facility like Zoom (https://zoom.us/).The lectures include concise theories, worked examples/calculations, derivation of formulae, and theoretical concepts. The lectures are strongly linked to the tutorial sessions, where students solve problems that follow Australian hydrological practice, based on Reference [24]. Tutorial sessions help students to understand the calculations, application of hydrological concepts, and professional practice. Students learn how to delineate catchment boundaries using the PDF-XChange Editor tool (https://www.tracker-software.com/product/pdf-xchange-editor). They also learn how to use Excel to analyze real-world hydrological data series. Students learn how to use some other advanced hydrological modeling tools in the ENV4107 Water Resources Engineering course. A few YouTube and engineering videos are also used to give good visualizations of various hydrological concepts. Industry speakers (a professional water engineer and entrepreneur) are invited to talk on contemporary issues in engineering hydrology.

\subsection{Course Assessment}

The course assessment follows a traditional approach, involving two assignments (each weighted at $25 \%$ ) and a $2 \mathrm{~h}$ final examination (50\%). Students submit both assignments individually, and a submission template is provided for consistency. A marking scheme is included at the end of each 
assignment so that students can understand the relative weighting of each component. To receive a passing grade, a student must obtain at least $50 \%$ of the total weighted marks available for the course (primary hurdle), and at least $40 \%$ of the weighted marks available for the final examination (secondary hurdle). Both assignments are predominantly computational and follow industrial practice in Australia. Students use Excel spreadsheets to undertake hydrological analyses, using real-world hydrological data. In each module, an online self-assessment quiz is uploaded to StudyDesk, which includes 10 to 15 multiple-choice questions. Students are able to test their understanding by attempting the online quiz several times.

The first assignment is designed to test students' achievement in learning objectives 1 to 5 , covering modules 1 to 5, respectively. In particular, the first assignment involves rainfall and stream flow data measurement and presentation, flood frequency analyses using annual and partial series and design flood estimation, design rainfall estimation using rainfall intensity frequency duration (IFD) curves, and estimation of peak discharges. The first assignment is designed to reinforce and extend students' knowledge of hydrological methods and the uncertainty associated with design flood estimation. A stream gauge site is provided to students and they estimate design flood discharges for a range of annual exceedance probabilities (AEP), using four techniques, namely, annual series (log Pearson type 3 distribution), partial series (negative exponential distribution), quantile regression [25], and the regional flood frequency estimation (RFFE) tool [3]. Incorporation of some other important techniques, such as Bayesian approaches and uncertainty analysis, will be considered in future. Industrial practices followed in the first assignment are described in Table 1 (Modules 1 to 5).

The second assignment is designed to test students' achievement in learning objectives 6,7 , and 8 , corresponding to Modules 6, 7, and 8, respectively. The second assignment involves estimation of a hydrograph in a sub-catchment outlet, considering storage or channel routing (Module 6); estimation of minor and major design flows for a residential sub-division stormwater drainage plan (Module 7); and yield analysis for a feasibility study of a proposed water supply dam (Module 8). A sub-divisional stormwater drainage plan is provided to students and they use three design sheets (Excel spreadsheets) to estimate discharges to drainage pits and pipes for minor storms (10-year annual recurrence interval), and then check the flood hazard for major storms (100 year annual recurrence interval). Modules 6 to 8 in Table 1 provide the relevant industrial practices followed in the second assignment.

The final exam involves four questions. The first question includes 20 multiple-choice questions covering all learning objectives. There is no negative marking for wrong answers in the multiple-choice section. The other three questions are predominantly mathematics-based and they are randomly selected from different modules, but there is a guaranteed question from Module 9 (groundwater hydrology) to cover learning objective 9. Each question is divided into three or four sub-questions. A mathematical formula sheet is provided to students. Students are allowed to use a non-programmable calculator in the exam.

\subsection{Alignment with Industry Practices}

Hydrological practice in Australia is mainly guided by Australian Rainfall and Runoff (ARR)-A Guide to Flood Estimation [24]. ARR 1987 was significantly revised and modified in 2016, and the course contents were revised to cope with the changes in the ARR 2016 [24]. ARR 2016 includes nine books, and each book contains several chapters. Another important regional practice guide is the Queensland Urban Drainage Manual (QUDM) [26], which is followed in Module 7 (urban drainage). Hydrological data in Australia are available online, and students use real-world hydrological data for their analyses. In the tutorial sessions, students solve real-world hydrological problems based on Australian industrial practices. Table 1 provides a summary of different industrial practices followed in different modules of the course, and how students are engaged to solve real-world problems in the tutorial sessions. 
Table 1. Industry practices followed in the course.

\begin{tabular}{|c|c|}
\hline Course Modules & Industrial Practice Components \\
\hline $\begin{array}{l}\text { Module 1: } \\
\text { Hydrological } \\
\text { processes }\end{array}$ & $\begin{array}{l}\text { Queensland Government: Water } \\
\text { Monitoring Information Portal } \\
\text { ( }{ }^{1} \text { web address) }\end{array}$ \\
\hline
\end{tabular}
Active Learning in Tutorial Sessions

A topographic map (VicMap, for example) $\left({ }^{2}\right.$ web address) is provided to students, and they define the catchment boundary for a discharge point using the PDF-XChange Editor software ( ${ }^{3}$ web address). processes $\left({ }^{1}\right.$ web address $)$ Students gain familiarity with the Water Monitoring Data Portal, they collect streamflow data in different units $\left(\mathrm{m}^{3} / \mathrm{s}\right.$, mega liter, and $\left.\mathrm{mm}\right)$ for a creek gauge location and extract a flood hydrograph data for a flood period (January 2011 flood in Brisbane, for example).

\begin{tabular}{|c|c|c|c|c|}
\hline $\begin{array}{l}\text { Module 2: } \\
\text { Hydrological } \\
\text { measurements }\end{array}$ & - & $\begin{array}{l}\text { ARR } 2016 \text { Book } 1 \text { : Scope and Philosophy } \\
\text { (Chapter } 4 \text {-Data) }\left({ }^{4} \text { web address) }\right. \\
\text { Bureau of Meteorology (BOM): Climate } \\
\text { Data Online }\left({ }^{5} \text { web address) }\right. \\
\text { Queensland Government: Water } \\
\text { Monitoring Information Portal } \\
\text { ( }{ }^{1} \text { web address) }\end{array}$ & & $\begin{array}{l}\text { Students download Pluviograph rainfall data for a } \\
\text { catchment for a flood period (same as Module } 1 \text { ), and } \\
\text { then plot a rainfall hyetograph and estimate rainfall } \\
\text { intensity at different time resolutions, daily rainfall, and } \\
\text { total storm rainfall. } \\
\text { Students are provided with a topographic map with a } \\
\text { catchment boundary and BOM rainfall stations. They } \\
\text { collect daily rainfall data from the BOM website for a } \\
\text { flood period (same as in Module } 1 \text { and } 2 \text { ) and then } \\
\text { estimate areal average rainfall for the catchment using } \\
\text { different techniques, such as the Thiessen polygon, } \\
\text { isohyetal, and arithmetic mean techniques. }\end{array}$ \\
\hline
\end{tabular}

\begin{tabular}{|c|c|c|c|c|}
\hline $\begin{array}{l}\text { Module 3: Floods } \\
\text { and flood frequency } \\
\text { analysis }\end{array}$ & $\begin{array}{l}- \\
- \\
-\end{array}$ & $\begin{array}{l}\text { ARR } 2016 \text { Book 1: Scope and Philosophy } \\
\text { (Chapter 2-fundamental issues, Chapter } \\
\text { 3-approaches to flood estimation, and } \\
\text { Chapter 4-data) } \\
\text { ARR } 2016 \text { Book 3: Peak Flow Estimation } \\
\text { (Chapter 2-at-site flood frequency } \\
\text { analysis, Chapter 3-regional } \\
\text { flood methods) } \\
\text { Queensland Government: Water } \\
\text { Monitoring Information Portal } \\
\text { ('1 }{ }^{1} \text { eb address) }\end{array}$ & - & $\begin{array}{l}\text { Students collect } 20 \text { years of streamflow data for a creek } \\
\text { from the water monitoring information portal }\left({ }^{1} \text { web }\right. \\
\text { address) and then perform annual and partial series } \\
\text { flood frequency analyses using the log Pearson type } 3 \\
\text { (LP3) and negative exponential (NExp) distribution, } \\
\text { respectively. They plot the flood frequency chart with } \\
\text { the fitted LP3 and NExp curve with 5\% and } 95 \% \\
\text { confidence limits. Finally, they estimate design discharge } \\
\text { for different AEPs. }\end{array}$ \\
\hline $\begin{array}{l}\text { Module 4: Design } \\
\text { rainfalls }\end{array}$ & $\begin{array}{l}- \\
-\end{array}$ & $\begin{array}{l}\text { ARR } 2016 \text { Book 2: Rainfall Estimation } \\
\text { (Chapter 3-design rainfall, Chapter } \\
\text { 4-areal reduction factor, Chapter } \\
\text { 5-temporal patterns, Chapter 6-spatial } \\
\text { patterns of rainfall) } \\
\text { BOM: Design Rainfall Data System } \\
\text { ( }{ }^{6} \text { web address) }\end{array}$ & - & $\begin{array}{l}\text { The coordinates of a catchment centroid are provided to } \\
\text { students. They collect design rainfall data from the BOM } \\
\text { website ( }{ }^{6} \text { web address) and use the ARR data hub }\left({ }^{7} \text { web }\right. \\
\text { address) to estimate } 1 \text { in } 20 \text { AEP } 6 \text { h design point and } \\
\text { areal rainfall and temporal patterns of design rainfall, } \\
\text { and finally estimate design storm hyetograph. }\end{array}$ \\
\hline $\begin{array}{l}\text { Module 5: } \\
\text { Estimating peak } \\
\text { discharge }\end{array}$ & $\begin{array}{l}- \\
-\end{array}$ & $\begin{array}{l}\text { ARR } 2016 \text { Book 3: Peak Flow Estimation } \\
\text { (Chapter 2-at-site flood frequency } \\
\text { analysis, Chapter 3-regional } \\
\text { flood methods) } \\
\text { ARR Data Hub ( }{ }^{7} \text { web address) }\end{array}$ & - & $\begin{array}{l}\text { Students compile } 1 \%, 2 \%, 5 \%, 10 \%, 20 \% \text {, and } 50 \% \text { AEP } \\
\text { peak discharge estimates for a stream gauge site using } \\
\text { the regional flood frequency estimation (RFFE) online } \\
\text { tool (https://rffe.arr-software.org/). } \\
\text { Students apply the time-area method to estimate } \\
\text { discharge hydrograph and peak discharge for a } \\
\text { catchment during a storm event usinga rainfall intensity } \\
\text { hyetograph (provided) and considering } 60 \% \text { rainfall } \\
\text { excess and time of concentration of } 1 \mathrm{~h} \text {. }\end{array}$ \\
\hline $\begin{array}{l}\text { Module 6: } \\
\text { Estimating discharge } \\
\text { hydrographs }\end{array}$ & - & $\begin{array}{l}\text { ARR } 2016 \text { Book 5: Flood Hydrograph } \\
\text { Estimation (Chapter 2-catchment } \\
\text { representation, Chapter 3-losses) }\end{array}$ & - & $\begin{array}{l}\text { Students are provided with a rainfall intensity } \\
\text { hyetograph for a storm and they estimate rainfall excess } \\
\text { and maximum 10min rainfall excess depth considering } \\
\text { the loss models of IC (initial and continuing loss of } 2 \mathrm{~mm} \\
\text { and } 1.5 \mathrm{~mm} / \mathrm{h} \text {, respectively), and IP (initial and } \\
\text { proportional loss of } 10 \mathrm{~mm} \text { and } 0.4 \text {, respectively). } \\
\text { Students estimate outflow hydrograph from a river reach } \\
\text { for a given inflow hydrograph using the Muskingum } \\
\text { channel routing method. }\end{array}$ \\
\hline $\begin{array}{l}\text { Module 7: Urban } \\
\text { drainage hydrology }\end{array}$ & $\begin{array}{l}- \\
-\end{array}$ & $\begin{array}{l}\text { ARR } 2016 \text { Book 9: Runoff in Urban Areas } \\
\text { (Chapter 2-aspects of urban hydrology, } \\
\text { Chapter 5—-stormwater conveyance) } \\
\text { QUDM-Queensland Urban Drainage } \\
\text { Manual (Chapter 4-catchment } \\
\text { hydrology, Chapter 7-urban drainage) }\end{array}$ & & $\begin{array}{l}\text { Students are provided with a residential subdivision } \\
\text { layout, which includes a few stormwater drainage pits } \\
\text { and pipes. They estimate minor storm (2-year ARI) } \\
\text { discharge draining to pits and pipes and then check the } \\
\text { flood hazard for a major storm ( } 100 \text { year ARI) at a road } \\
\text { section downstream of the layout. Design sheet } \\
\text { templates for minor and major flood checks are provided } \\
\text { to the students. Students follow the QUDM and ARR } \\
2016 \text { stormwater drainage design guidelines. }\end{array}$ \\
\hline
\end{tabular}


Table 1. Cont.

\begin{tabular}{|c|c|c|}
\hline Course Modules & Industrial Practice Components & Active Learning in Tutorial Sessions \\
\hline $\begin{array}{l}\text { Module 8: } \\
\text { Estimating } \\
\text { catchment water } \\
\text { volumes }\end{array}$ & $\begin{array}{l}\text { - } \quad \text { ARR } 2016 \text { Book 5: Flood Hydrograph } \\
\text { Estimation (Chapter 5-flood routing } \\
\text { principles, Chapter 6-flood hydrograph } \\
\text { modeling approaches) } \\
\text { - } \quad \text { Australian Water Balance Model (AWBM) }\end{array}$ & $\begin{array}{l}\text { - Students estimate daily runoff volumes from a water } \\
\text { supply catchment using the simplified Australian Water } \\
\text { Balance Model (AWBM) (performed in Excel), and they } \\
\text { collect rainfall records from the BOM website. } \\
\text { Students perform a yield analysis and supply reliability } \\
\text { for a water supply dam. They collect rainfall and } \\
\text { evaporation data from the BOM website and use the } \\
\text { simplified AWBM for runoff estimation. }\end{array}$ \\
\hline $\begin{array}{l}\text { Module 9: } \\
\text { Groundwater } \\
\text { hydrology }\end{array}$ & $\begin{array}{l}\text { - } \quad \text { National Groundwater Information } \\
\text { System }\left({ }^{8} \text { web address }\right)\end{array}$ & $\begin{array}{l}\text { - } \\
\text { Students gain familiarity with the National } \\
\text { - } \\
\text { Students solve a few theoretical problems such as } \\
\text { calculating discharge, Darcy velocity, and seepage } \\
\text { velocity for water flowing through a sand column. They } \\
\text { estimate different aquifer properties, such as specific } \\
\text { yield, transmissivity and hydraulic conductivity, and } \\
\text { pumping rate for the equilibrium test. }\end{array}$ \\
\hline Revision & $\begin{array}{l}\text { - Industry lecture on catchment modeling, } \\
\text { urban drainage, and WSUD }\end{array}$ & \\
\hline
\end{tabular}

\subsection{Course Evaluation}

\subsubsection{Student Engagement}

There were 107enrolled students in the course in the second semester of 2018, where the numbers of on-campus and online students were $31(29 \%)$ and $76(71 \%)$, respectively. Among the on-campus students, 21 were on the Toowoomba campus and the remaining10 students were on the Springfield campus. A $2 \mathrm{~h}$ lecture and a $2 \mathrm{~h}$ tutorial session were held weekly on the Toowoomba campus, whereas a combined $4 \mathrm{~h}$ lecture and tutorial was held weekly on the Springfield campus. Lectures and tutorial sessions were recorded during class time and subsequently uploaded to StudyDesk. Their view numbers were not counted.

In order to engage students, self-assessment online practice quizzes were included in every module. There were no allocated marks for completing the online self-assessment quizzes, but students were highly recommended to do them in order to test their understanding in each module. There was a separate discussion forum for every module, where students asked questions and other students and the examiner provided responses. Separate discussion forums were also included for the two assignments and for the final examination. Final examination questions from previous years were included in the StudyDesk materials so that students could solve them independently and raise any questions regarding the solutions in the forums. Both assignments were students' individual work; there was no formal group or teamwork in this course. However, students could discuss problems with their classmates in the tutorial sessions, and some students formed online study groups for discussions. Since more than $70 \%$ of students were online students, ensuring their engagement in the course was a challenging task. Students' engagement in the course was monitored and estimated by their attempts at the online self-assessment quizzes and by their participation in the discussion forums.

\subsubsection{Student Assessment of Course and Learning Outcomes}

At the end of the semester, students were highly encouraged to complete the course assessment on StudyDesk using the MyOpinion Table. MyOpinion involves questions related to the course and to the teaching quality of the academic staff. Students provide a grade for each question on a scale from 1 to 5 ( 1 = strongly disagree, $2=$ disagree, $3=$ neither agree nor disagree, $4=$ agree, $5=$ strongly 
agree). Students could also write their opinions and comments on the best aspects and potential improvements of the course. In addition to the MyOpinion course evaluation, an online survey was conducted for student assessment of learning outcomes. For each of the course's intended learning outcomes, students were requested to assign an appropriate numerical grade $(1=$ very low, $2=$ low, $3=$ medium, $4=$ high, $5=$ very high) corresponding to the extent that they felt the course helped them to achieve the outcome over the semester.

\section{Results and Discussion}

\subsection{Student Engagement}

Students' engagement in the course was evaluated based on their participation in the self-assessment quizzes (SAQ) and in the discussion forums. The online SAQ involved multiple-choice questions with only one correct answer. Students were able to attempt the quiz as many times as they wanted, but every time they attempted, the question and answer sequence was shuffled. Figure 1 shows the total number of attempts, the number of students who participated in SAQ, and the number who received the highest score (100\% correct answers). The SAQ for modules 1, 2, and 3 involved 12 multiple-choice questions, whereas the SAQ for Module 6 involved 15 questions and the rest of the modules involved 10 questions. Figure 1 shows that at least 50 students (47\%) participated in all online self-assessment quizzes; however, a declining trend of participation was noticed from Module 1 to Module 9. About $81 \%$ of students participated in Module 1 . On average, $57 \%$ of the participating students achieved the highest grade ( $100 \%$ correct answers), and each student attempted on average about 2.8 times. The participation trend in Figure 1 does not indicate that students were active at the beginning of the semester and became gradually less active as the semester progressed; actually, all the SAQs were kept open and students could participate at any time in any module throughout the semester.

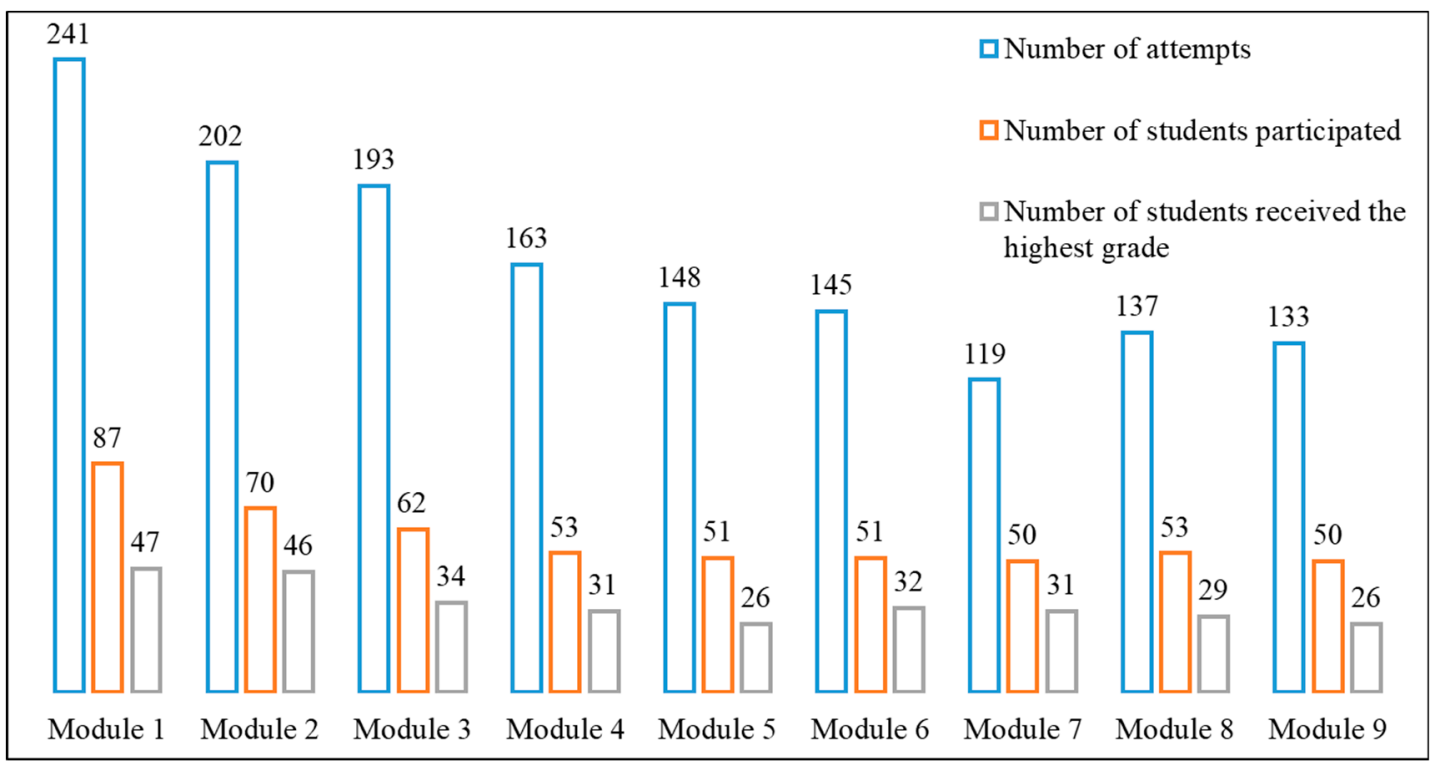

Figure 1. Participation in online self-assessment quizzes (numbers at top of each bar indicate number of attempts and number of students).

Participation in the discussion forums was highly recommended, and it was one of the major platforms for online/external students' engagement in the course. All the forums were kept open throughout the semester. Course students, irrespective of their on-campus or online enrolment, were able to write a question in the forum, and other students and the academic staff could reply to that question. There were nine module-specific and three course-assessment-specific forums in the 
StudyDesk. Table 2 shows the number of discussion topics and the highest number of replies for a topic; however, it does not provide the number of students who participated in the forums. Table 2 shows the replies from the students only. It is shown that the maximum number of discussion topics were posted for Assignment 2, which involved urban drainage design (Module 7). The maximum number of replies was observed for a discussion topic on overland concentrated flow travel time, which was a part of the urban drainage design module (Module 7). Students also raised questions on Module 7 (urban drainage) in the final exam discussion forum. For the module-specific discussion forums, it was found that the most (12 topics) discussion topics were posted on flood frequency analysis (Module 3), whereas the fewest (one topic) was posted on groundwater hydrology (Module 9). The NExp distribution for partial series analysis (Module 3) received the maximum number of replies (13 replies) from students. The discussion forum for Assignment 1 received the maximum number of replies (14 replies) on annual and partial series frequency analysis (Module 3).

Table 2. Participation in the discussion forums.

\begin{tabular}{ccccc}
\hline Discussion Forum & $\begin{array}{c}\text { Number of } \\
\text { Discussion Topics }\end{array}$ & $\begin{array}{c}\text { Highest Number } \\
\text { of Replies }\end{array}$ & $\begin{array}{c}\text { Discussion Topic with the } \\
\text { Highest Number of Replies }\end{array}$ & $\begin{array}{c}\text { Module/Learning } \\
\text { Objective }\end{array}$ \\
\hline Module specific & 52 & 13 & $\begin{array}{c}\text { Negative exponential distribution } \\
\text { for partial series }\end{array}$ & 3 \\
\hline Assignment 1 & 32 & 14 & $\begin{array}{c}\text { Annual and partial series } \\
\text { frequency analysis }\end{array}$ & 3 \\
\hline Assignment 2 & 49 & 14 & $\begin{array}{c}\text { Travel time for overland } \\
\text { concentrated flow }\end{array}$ & 7 \\
\hline Final examination & 24 & 17 & $\begin{array}{c}\text { Time of concentration for partial } \\
\text { and full area method }\end{array}$ & 7 \\
\hline
\end{tabular}

It was evident from the discussion forum topics and replies that students particularly raised questions about two modules, Module 3-flood and flood frequency analysis and Module 7-urban drainage hydrology. Module 3 was heavily statistics-based, where students downloaded real-world stream flow data and used them for flood frequency analysis using the log Pearson type 3 (LP3) and negative exponential (NExp) distributions for annual and partial series, respectively. Module 7 involved estimation of stormwater discharge for drainage pits and pipes for a minor storm (2-year Average Recurrence Interval-ARI storm) and then a major flood hazard check considering a 100-year ARI storm.

\subsection{Students' Achievement of Learning Outcomes}

There were nine learning outcomes in the course. Students were requested to rate their learning achievement for each learning outcomes on a scale from 0 (very low) to 5 (very high). Figure 2 shows the average scores of students' achievement of the course learning outcomes (CLOs). Although a small number of students participated in the survey (16 students), it showed that achievement in the learning outcomes was high (average score $>4.4$ ) for CLOs 1 to 8 , but a bit low (average score $=3.9$ ) for CLO 9, which was related to groundwater hydrology (Module 9). The relative weighting of Module 9 (groundwater hydrology) in the course was 5\%, and it covered the yield characteristics of aquifers. Considering the importance of groundwater in Australia and the relatively low achievement of this learning outcome, there may be a necessity to reconsider the relative weighting as well as the content of this module. 


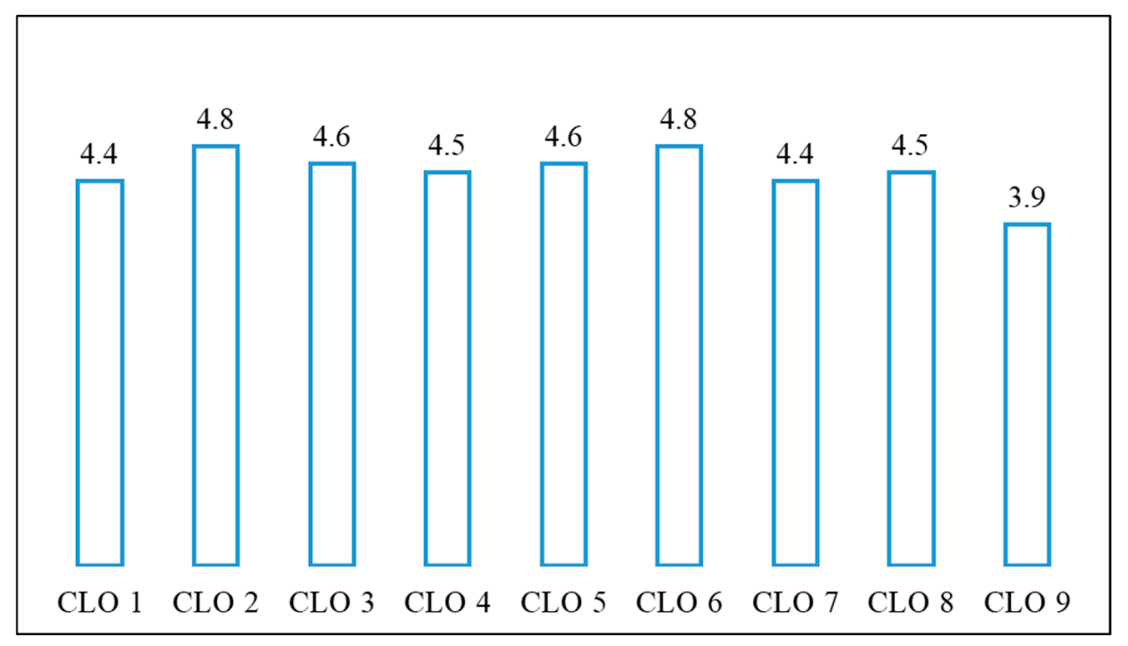

Figure 2. Assessment of course learning outcomes (average scores are shown at the top of each bar, number of students who participated $=16$ ).

\subsection{Students' Evaluations of the Course}

Students were requested to provide their anonymous evaluation and comments on the course. Table 3 shows the mean scores of students' evaluations for some selected questions from the MyOpinion. Selected questions in Table 3 include course-related evaluation questions, but the teaching-related evaluation questions have been excluded. The mean scores for the study area are also shown for comparison. Generally, a score between 4 (agree) and 5 (strongly agree) was considered a very good score. Students' evaluation scores are shown separately for on-campus and online students. Table 3 shows that online students (35\% respondents) were highly satisfied with the course, and their satisfaction levels (mean scores) were higher than the Toowoomba on-campus students (33\% respondents), except for the technology environment relation question (number 6). Springfield on-campus students ( $27 \%$ respondents) provided the highest satisfaction scores in all questions. Compared to the mean scores in the study area, ENV3105 Hydrology received very good scores in all course-related evaluation questions. The course evaluation in 2018 was improved significantly compared to the previous evaluations (taught by different academic staff) where the average evaluation score was about 3 out of 5 .

Table 3. Evaluation of the course ona scale from 1 (strongly disagree) to 5 (strongly agree), mean scores are shown in the table (" $n$ " indicates number of students that participated in the survey/total students).

\begin{tabular}{|c|c|c|c|}
\hline \multirow[b]{2}{*}{ Questions } & \multicolumn{2}{|c|}{ On-Campus Students } & \multirow{2}{*}{$\begin{array}{c}\text { Online } \\
\text { Students } \\
(n=25 / 72)\end{array}$} \\
\hline & $\begin{array}{l}\text { Toowoomba } \\
(n=7 / 21)\end{array}$ & $\begin{array}{l}\text { Springfield } \\
(\mathrm{n}=3 / 11)\end{array}$ & \\
\hline 1. Overall satisfaction with the course & 4.29 & 4.67 & 4.4 \\
\hline 2. Course materials provided clear information & 4.14 & 4.67 & 4.32 \\
\hline 3. Course materials supported students' learning & 4.14 & 5.00 & 4.36 \\
\hline 4. Course structure supported students' learning & 4.14 & 4.67 & 4.28 \\
\hline 5. Assessment tasks contributed to students' learning & 4.29 & 4.67 & 4.52 \\
\hline $\begin{array}{l}\text { 6. Technology environment allowed students to do } \\
\text { what they need }\end{array}$ & 4.14 & 4.67 & 4.12 \\
\hline 7. Course StudyDesk supported students' learning & 4.14 & 4.67 & 4.32 \\
\hline
\end{tabular}

The summarized students' comments from the MyOpinion survey are provided in Table 4. There were three specific questions, related to best aspects of the course, improvement needed, and anything 
else. It showed that on-campus students from both campuses enjoyed the course contents and the delivery mechanism. Online students appreciated the flexibility, real-world and work related examples and assignments, active discussion forums, and easy to follow, well-structured materials in StudyDesk. In terms of improvements, both on-campus and online students recommended that more worked examples be included in the course (in particular for Module 7-urban drainage). Online students suggested that the lecture and tutorial video quality be improved, and they recommended excel training for the data analyses to be included in the course. Most online students were work-based students, and it was clear from their comments that they liked industry-based learning so that they could apply the knowledge in real-world applications, including their work locations. Flexibility was the aspect that most work-based students preferred. The discussion forums were the only platform where online students interacted with each other and with academic staff. A timely response from academic staff in the forums was highly expected by online students.

Table 4. Anonymous constructive comments on the course.

\begin{tabular}{|c|c|c|c|c|c|c|}
\hline \multirow{2}{*}{\multicolumn{2}{|c|}{ Questions }} & \multicolumn{4}{|c|}{ On-Campus Students } & \multirow{2}{*}{ Online Students } \\
\hline & & & Toowoomba & & Springfield & \\
\hline 1. & $\begin{array}{l}\text { What were the best } \\
\text { aspects of this course? }\end{array}$ & - & $\begin{array}{l}\text { Course delivery } \\
\text { Tutorial contents }\end{array}$ & - & $\begin{array}{l}\text { Lecture and } \\
\text { tutorial contents } \\
\text { Course delivery } \\
\text { Assignments } \\
\text { linked to study } \\
\text { book and tutorials }\end{array}$ & $\begin{array}{ll}- & \text { Course content } \\
- & \text { Challenging assignments } \\
- & \text { Flexibility } \\
- & \text { Clear study book } \\
\text { Tutorials are linked to real-world } \\
\text { online database } \\
-\quad & \begin{array}{l}\text { Regular development of materials } \\
-\end{array} \\
\text { Practical resources related to work } \\
- & \text { Real-life applications, particularly in } \\
\text { - } & \text { Active discussion forum } \\
- & \text { Well organized online materials } \\
- & \text { Easy to follow worked examples } \\
\text { and tutorials }\end{array}$ \\
\hline 3. & $\begin{array}{l}\text { Is there anything else } \\
\text { you want to tell us } \\
\text { about this course? }\end{array}$ & - & $\begin{array}{l}\text { Need more groundwater } \\
\text { content (Module 9) }\end{array}$ & - & $\begin{array}{l}\text { Active discussion } \\
\text { forums support } \\
\text { the learning }\end{array}$ & $\begin{array}{l}\text { More active discussion forums } \\
\text { are needed }\end{array}$ \\
\hline
\end{tabular}

\section{Conclusions}

The main concern of engineering education is to prepare engineering graduates for employment. Engineering students should develop three major skill sets (employability, problem solving, and design skills) in their engineering program. Employability skills involve skills in communication, teamwork, and project management. However, teamwork was not taught in this course. Engineering curricula need to be flexible enough to accommodate new science and innovation, tools, and technologies, and their application and practice in the engineering profession. Engineering education should adopt outcomes-based and student-centered curricula, engagement of academic staff in education research, and involvement of students in engineering practice.

Industrial careers in hydrology involve extensive use of data (climate, streamflow, and GIS, for example) and modeling applications. There is a need for hydrology students to learn these skills. Availability of resources such as models, data, and scientific toolsets has created the opportunity to re-conceptualize the hydrology curriculum to integrate these new resources. A few simplistic models (rational method, probability distribution, and the RFFE tool, for example) were used in this course. Different toolsets are available for hydrological modeling and data analyses, such as computing environments for data processing (Excel, ArcGIS, for example), toolbars or extensions added to computing environments, and numerical models. Amongst these computing tools, Excel and 
ArcGIS are widely used in hydrology courses. In a changing student population where more students are work-based, online education is gaining popularity for both work-based and fulltime students, without compromising the importance and incorporation of professional practice.

Engineering programs in Australia must comply with the outcomes expressed in the ten level Australian Qualifications Framework [27]. For each level, program outcomes are expressed in terms of knowledge, skills, and application of knowledge and skills. In addition to AQF, engineering programs are expected to meet the requirements of professional accreditation bodies like Engineers Australia (EA). Professional accreditation assures employers that engineering graduates have the knowledge, skills, and personal attributes to commence practice in their profession. Industries are the most important customers of engineering education. Without sufficient inclusion of industrial practice in the curricula, it is expected that graduates will struggle to meet the changing needs of industry in a competitive environment. Consequently, the accreditation criteria for engineering programs are outcomes-based and provide more emphasis on design capability and professional skills. For better achievement of course learning outcomes, it is necessary that course assessment strategies align with course learning outcomes. The ENV3105 Hydrology course at the University of Southern Queensland shows how industry practices in hydrology can be accommodated in course learning and assessment tools in order to achieve learning outcomes. Emphasis should be given to enhancing students' engagement by adopting different strategies, including self-assessment quizzes and discussion forums. The approach followed in the course may be useful for other engineering courses.

Funding: This research received no external funding.

Conflicts of Interest: The authors declare no conflicts of interest.

\section{References}

1. Merwade, V.; Ruddell, B.L. Moving university hydrology education forward with community-based geoinformatics, data and modeling resources. Hydrol. Earth Syst. Sci. 2012, 16, 2393-2404. [CrossRef]

2. Ruddell, B.L.; Wagener, T. Grand challenges for hydrology education in the 21st century. J. Hydrol. Eng. 2015, 20, A4014001. [CrossRef]

3. Rahman, A. A blended learning approach to teach fluid mechanics in engineering. Eur. J. Eng.Educ. 2017, 42, 252-259. [CrossRef]

4. Bourne, J.; Harris, D.; Mayadas, F. Online engineering education: Learning anywhere, anytime. J. Eng. Educ. 2005, 94, 131-146. [CrossRef]

5. Allen, I.E.; Seaman, J. Going the Distance: Online Education in the United States; Sloan Consortium: Newbury Port, MA, USA, 2011.

6. Reeves, T.C.; Herrington, J.; Oliver, R. Authentic activities and online learning. In Proceedings of the 25th HERDSA Annual Conference, Perth, Australia, 7-10 July 2002; pp. 562-567.

7. Koehn, E. Enhancing civil engineering education and ABET criteria through practical experience. J. Prof. Issues Eng. Educ. Pract. 2004, 130, 77-83. [CrossRef]

8. Smith, N.M.; Smith, J.M.; Battalora, L.A.; Teschner, B.A. Industry-university partnership: Engineering education and corporate social responsibility. J. Prof. Issues Eng. Educ. Pract. 2018, 144, 04018002. [CrossRef]

9. Arlett, C.; Lamb, F.; Dales, R.; Willis, L.; Hurdle, E. Meeting the needs of industry: The drivers for change in engineering education. Eng. Educ. 2010, 5, 18-25. [CrossRef]

10. Bodmer, C.; Leu, A.; Mira, L.; Rütter, H. SPINE: Successful Practices in International Engineering Education, Engineers Shape our Future; IngCH: Zürich, Switzerland, 2002.

11. Spinks, N.; Silburn, N.; Birchall, D. Educating Engineers for the 1st Century: The Industry View; The Royal Academy of Engineering: London, UK, 2006.

12. World Chemical Engineering Council (WCEC). How Does Chemical Engineering Education Meet the Requirements of Employment? WCEC: Frankfurt, Germany, 2004.

13. Bons, W.; McLay, A. Re-engineering engineering curricula for tomorrow's engineers. In Proceedings of the 14th Annual Australasian association for Engineering Education Conference, Melbourne, Australia, 29 September-1 October 2003. 
14. Nair, C.S.; Patil, A.; Mertova, P. Re-engineering graduate graduate skills-A case study. Eur. J. Eng. Educ. 2009, 34, 131-139. [CrossRef]

15. Scott, G.; Yates, K.W. Using successful graduates to improve the quality of undergraduate engineering programmes. Eur. J. Eng. Educ. 2002, 27, 363-378. [CrossRef]

16. Ashman, P.J.; Scrutton, S.; Stringer, D.; Mullinger, P.J.; Willison, J. Stakeholder perceptions of chemical engineering graduate attributes at the University of Adelaide. In Proceedings of the Chemeca, Newcastle City Hall, New South Wales, Australia, 28 September-1 October 2008.

17. Male, S.A.; Bush, M.B.; Chapman, E.S. Perceptions of competency deficiencies in engineering graduates. Australas. J. Eng. Educ. 2010, 16, 55-67. [CrossRef]

18. Williams, B.S. Review of the Discipline of Engineering; Report and Recommendation; Commonwealth of Australia: Canberra, Australia, 1988; Volume 1.

19. Johnson, P. Changing the Culture: Engineering Education into the Future: Task Force Reports; The Institution of Engineers: Sydney, Australia, 1996.

20. Johnson, A.; King, R.; Bradley, A.; O'Kane, M. Addressing the Supply and Quality of Engineering Graduates for the New Century; The Carrick Institute for Learning and Teaching in Higher Education: Sydney, Australia, 2008.

21. Harris, S. Why are engineering firms struggling to recruit graduates? The Engineer Magazine, 1 April 2014.

22. Sinobas, L.R.; Calvo, R.S. Encouraging the learning of hydraulic engineering subjects in agricultural engineering schools. Eur. J. Eng. Educ. 2014, 39, 483-495. [CrossRef]

23. Brodie, I.M.; Hellyer, L. Comparison of plagiarism rates between oncampus and offcampus engineering hydrology students. In Proceedings of the 40th SEFI Annual Conference 2012-Engineering Education 2020: Meet the Future, Thessaloniki, Greece, 23-26 September 2012.

24. Ball, J.; Babister, M.; Nathan, R.; Weeks, W.; Weinmann, E.; Retallick, M.; Testoni, I. Australian Rainfall and Runoff: A Guide to Flood Estimation 2016; Commonwealth of Australia (Geoscience Australia): Symonston, Australia, 2016.

25. Palmen, L.B.; Weeks, W.D. Regional Flood Frequency for Queensland Using the Quantile Regression Technique. Australas. J. Water Resour. 2011, 15, 47-57. [CrossRef]

26. Institute of Public Works Engineering Australasia (IPWEA). Queensland Urban Drainage Manual 2013; IPWEA Queensland, Australia: Queensland, Australia, 2013.

27. Australian Qualifications Framework (AQF). Australian Qualifications Framework, 2nd ed.; Australian Qualifications Framework Council: Adelaide, Australia, 2013. 